\title{
Public Opinions about Rangeland Resources in Northeast Nevada
}

\section{Survey respondents express need for multiple use.}

\author{
By J. Kent McAdoo
}

In the $21^{\text {st }}$ century, users and managers of rangelands face numerous challenges. Among them are education, proper application of science, multiple use management, and cooperation among diverse user groups.

Great Basin rangelands are "filling up" in the sense that more people are discovering and using resources that historically were used by comparatively few. How society responds to these challenges will affect future generations. The health of rangeland ecosystems, sustained agricultural production, and continued use of natural resources are at stake. Productive rangelands, i.e., rangelands with properly functioning ecological processes, will provide these values.

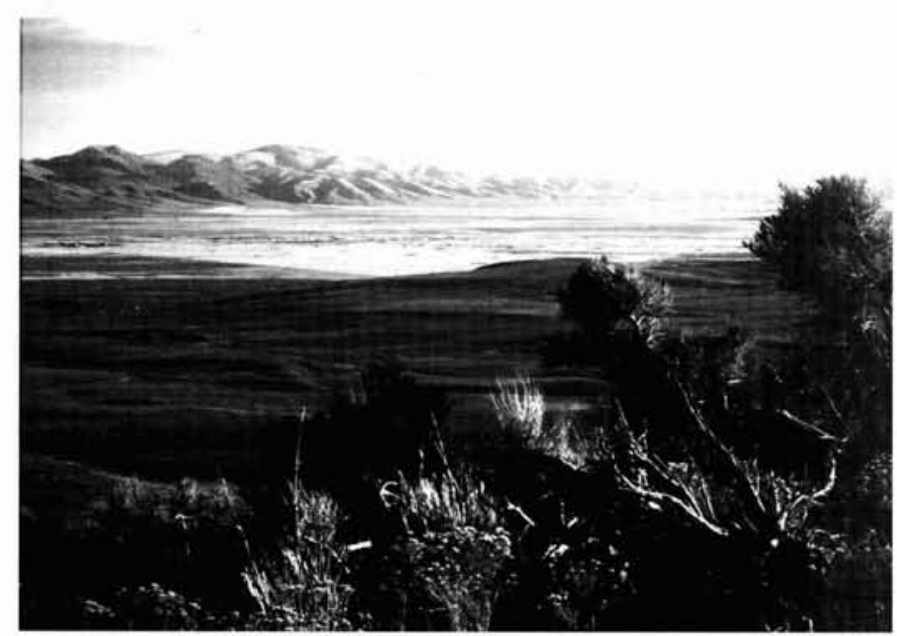

The ecological health of northeast Nevada rangelands is a priority public concern.

During an 18-month period in 1999-2000, an informal needs assessment was completed by documenting the rangeland resource issues discussed during 40-plus meetings of diverse focus groups. These included meetings of coordinated resource management teams, the Nevada Section of the
Society for Range Management, conservation districts, weed districts, Nevada Weed Management Association, riparian research groups, Nevada Cattlemen's Association, holistic management teams, Nevada Chapter of the Wildlife Society, and the Northeastern Nevada Stewardship Group. These groups represented a cross-section of the educational needs for both laymen and professional resource specialists.

Results of this informal needs assessment approach showed three major areas of emphasis: (1) restoration of rangeland productivity, (2) sustainable/multiple use of rangeland resources, and (3) resource conflict resolution.

\section{Survey Methods}

To further refine, formalize, and prioritize public input for education purposes, a written natural resources survey was prepared for distribution in 2001. Before this survey was mailed, a draft survey was sent to 20 reviewers, including ranchers, miners, members of the Northeastern Nevada Stewardship Group, and representatives from the Bureau of Land Management, U.S. Forest Service, Natural Resources Conservation Service, Nevada Department of Wildlife, and Nevada Division of Forestry. The survey targeted northeast Nevada, specifically Elko, Eureka, Lander, and White Pine counties.

To ensure an adequate sample size, 1,000 surveys were mailed. Survey recipients were chosen completely at random from the tax roles of the four counties. For equitable distribution, the number of surveys sent to residents of each county was stratified by county population. The survey questions were divided into three primary categories based on results of the previous informal needs assessment: (1) restoring rangeland productivity, (2) sustainable/multiple use of rangeland resources, and (3) resource conflict resolution. Each survey also included four general questions about economics and environment. 
A total of 246 surveys were returned, for a return rate of $25 \%$. Specific results of the survey are summarized by category below. Questions shown in tables are abbreviated to conserve space. Original questions provided background information when needed. Results of this survey were originally reported in a University of Nevada Cooperative Extension Fact Sheet (FS 01-38).

\section{Restoring Rangeland Productivity}

Those surveyed were asked to rate the importance of seven rangeland productivity challenges on a scale of 1 (very important) to 5 (not important). The majority of respondents rated rangeland health as the most important productivity challenge (Table 1).

Table 1. Relative importance of rangeland productivity challenges.

\begin{tabular}{l|c}
\hline \hline Challenge & $\begin{array}{c}\text { Rated as Important } \\
\text { to Very Important } \\
\text { (\% of Survey Respondents) }\end{array}$ \\
\hline Rangeland health & 81 \\
\hline Noxious weed control & 76 \\
\hline Burned area rehabilitation & 75 \\
\hline Wildlife habitat improvement & 73 \\
\hline Revegetation of cheatgrass-infested areas & 71 \\
\hline Livestock forage production & 67 \\
\hline Reclamation of mined land & 62 \\
\hline &
\end{tabular}

This was followed closely by the challenges of noxious weed control and burned area rehabilitation.

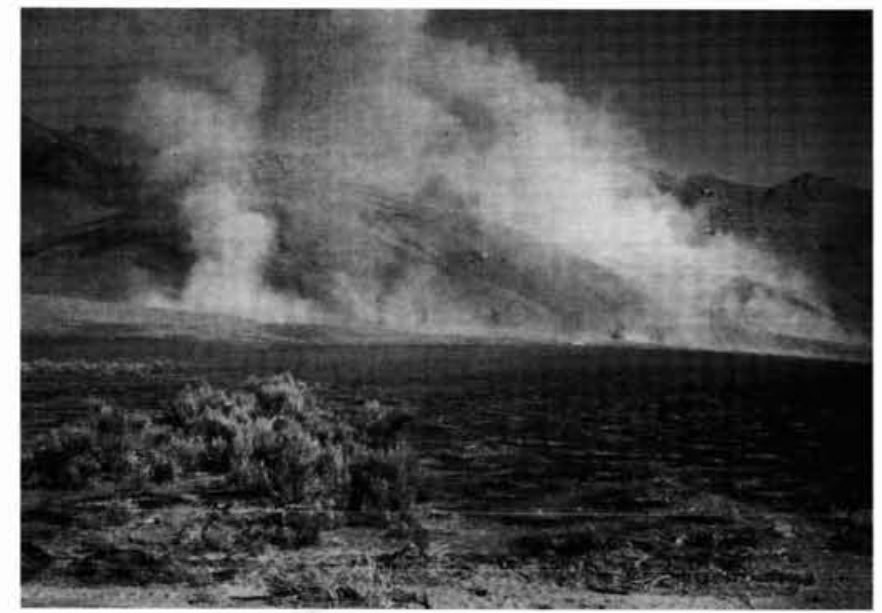

Land users are concerned about the recovery of rangelands impacted by noxious weeds and wildfire.

Respondents took the challenges of restoring rangeland productivity very seriously (Table 2 ). The increasing frequency of wildfire on rangeland and resulting cheatgrass invasions were considered as significant problems by a large majority of those surveyed (Table 2). Most respondents indicated that burned areas dominated by cheatgrass and threatened with invasion by noxious weeds should be revegetated with desirable species to limit establishment of undesirable vegetation. However, as important as the weed issue is, $90 \%$ of the respondents thought that most Nevada residents don't recognize noxious weeds.

Table 2. Survey responses to questions about restoring rangeland productivity.*

\begin{tabular}{|c|c|c|c|}
\hline \multirow[t]{2}{*}{ Question } & \multicolumn{3}{|c|}{ Responses (by \%) } \\
\hline & Yes & No & Unsure \\
\hline Do you think the increasing frequency of wildfires in northern Nevada is a serious problem? & 77 & 13 & 10 \\
\hline Is the invasion of the flammable, exotic annual cheatgrass a problem? & 83 & 7 & 11 \\
\hline $\begin{array}{l}\text { Does the possibility that cheatgrass areas may become dominated by noxious weeds put added emphasis on } \\
\text { revegetation of these areas with competitive desirable vegetation? }\end{array}$ & 80 & 4 & 16 \\
\hline Do you think most Nevada residents recognize noxious weed species and understand how they are spread? & 4 & 90 & 6 \\
\hline Is weed control sometimes a concern on mined land that is being revegetated? & 44 & 16 & 40 \\
\hline $\begin{array}{l}\text { Should the establishment of rangeland vegetation for livestock forage be a high priority goal for revegetation } \\
\text { efforts on public lands that have been burned or mined? }\end{array}$ & 74 & 16 & 10 \\
\hline $\begin{array}{l}\text { Should the establishment of rangeland vegetation for wildlife habitat be a high priority goal for revegetation } \\
\text { efforts on public lands that have been burned or mined? }\end{array}$ & 84 & 9 & 7 \\
\hline Should native plant species be used, when possible, to revegetate public lands that have been burned or mined. & 89 & 3 & 8 \\
\hline $\begin{array}{l}\text { When native plant species are cost prohibitive or difficult to establish, should adapted non-native plant species be } \\
\text { used to revegetate public lands that have been burned or mined? }\end{array}$ & 67 & 14 & 18 \\
\hline $\begin{array}{l}\text { Do you think there may be a market niche for local producers to grow varieties of desirable vegetation to keep up } \\
\text { with the demand for seed needed to revegetate burned or mined land? }\end{array}$ & 68 & 8 & 24 \\
\hline $\begin{array}{l}\text { Can livestock, prescribed fire, herbicides, and mechanical manipulation be used either individually or in combination } \\
\text { as vegetation management tools to sustain or improve rangeland productivity? }\end{array}$ & 77 & 4 & 19 \\
\hline $\begin{array}{l}\text { Is there a need for continuing education and research with regard to restoring rangeland productivity in } \\
\text { northern Nevada? }\end{array}$ & 87 & 6 & 7 \\
\hline
\end{tabular}

*Due to rounding errors, total response \% (by row) may range from 99 to $101 \%$ 


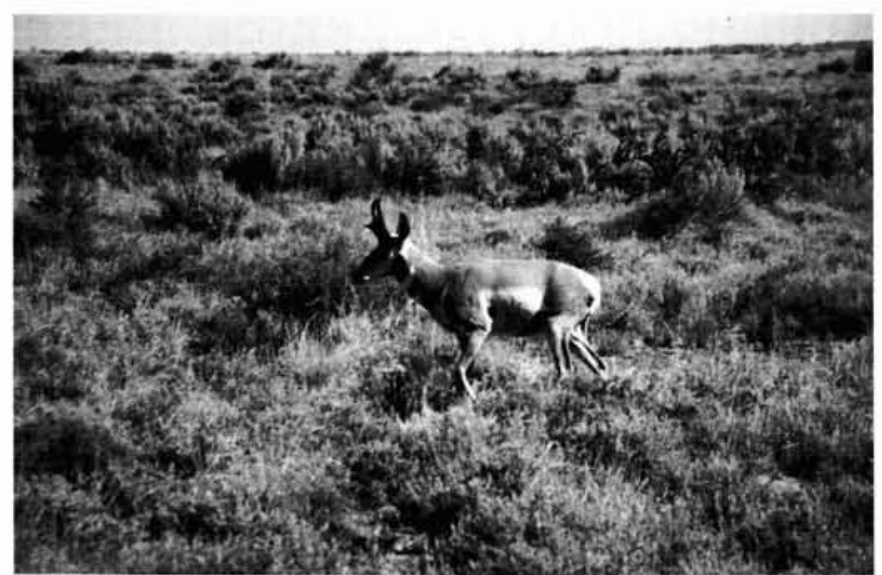

Wildlife habitat and species diversity was ranked as the most important use of rangelands.

The importance of weed control on revegetated mine sites was less obvious, with $44 \%$ of respondents concerned and $40 \%$ unsure. However, when asked about the importance of revegetating burned or mined public lands, $84 \%$ of the respondents agreed that wildlife habitat was a high priority goal and $74 \%$ viewed livestock forage similarly as high priority (Table 2). A large majority of the respondents indicated that native plant species should be used, when possible, to revegetate burned or mined public lands. In those situations where native plant species are cost prohibitive or difficult to establish, approximately two-thirds of the respondents favored use of adapted non-native species. Because of increasing demand for revegetating disturbed areas, most respondents thought a niche for local seed growers/suppliers may be emerging. Finally, most respondents saw a need for continuing education and research regarding the restoration of rangeland productivity in northern Nevada.
A majority of the respondents indicated that prescribed fire, livestock, herbicides, and mechanical manipulation can be used either individually or in combination as vegetation management tools to sustain or improve rangeland productivity. When asked to rate these tools by preference on a scale of 1 (highest) to 5 (lowest), $69 \%$ of the respondents rated livestock as the preferred vegetation management tool, followed by mechanical manipulation $(53 \%)$, prescribed fire $(43 \%)$, and herbicides $(22 \%)$.

\section{Sustainable/Multiple Use of Rangeland Resources}

When asked to rank six multiple uses on northern Nevada's rangelands on a scale of 1 (very important) to 5 (not important), respondents identified wildlife habitat and species diversity, watershed, and livestock forage as the most important rangeland uses (Table 3). However, 5 of the 6 uses were

Table 3. Relative importance of sustainable/multiple uses of rangeland resources.

\begin{tabular}{l|c}
\hline \hline Type of Use & $\begin{array}{c}\text { Rated as Important to Very Important } \\
\text { (\% of Survey Respondents) }\end{array}$ \\
\hline Wildlife habitat and diversity & 89 \\
\hline Watershed & 87 \\
\hline Livestock forage & 78 \\
\hline Recreation & 70 \\
\hline Mineral production & 61 \\
\hline Woodland products & 49 \\
\hline
\end{tabular}

rated by more than $60 \%$ of the respondents as being important to very important.

Most of the respondents indicated that wildlife habitat and diversity, watershed, livestock forage, recreation, mineral production, and woodland products are compatible uses of rangelands (Table 4).

Table 4. Survey responses to questions about sustainable/multiple uses of rangelands*

\begin{tabular}{|c|c|c|c|}
\hline Questions & \multicolumn{3}{|c|}{ Responses (by\%) } \\
\hline Are the multiple uses described in Table 3 generally compatible with each other? & $\begin{array}{l}\text { Yes } \\
66\end{array}$ & $\begin{array}{l}\text { No } \\
22\end{array}$ & $\begin{array}{l}\text { Unsure } \\
12\end{array}$ \\
\hline Do you think elk, deer, and cattle are compatible on rangelands? & 78 & 12 & 10 \\
\hline Do you think we should maintain the diversity of bird, mammal, and reptile species in sagebrush habitat? & 91 & 5 & 5 \\
\hline Are livestock and a wide diversity of wildlife species compatible on rangelands? & 78 & 9 & 13 \\
\hline Is hard-rock mining compatible with production of wildlife and livestock on rangelands? & 58 & 22 & 20 \\
\hline $\begin{array}{l}\text { Are the nonconsumptive rangeland uses such as hiking, backpacking, picnicking, wildlife viewing, } \\
\text { off-roading, and camping important to rangeland users? }\end{array}$ & 88 & 7 & 5 \\
\hline $\begin{array}{l}\text { Approximately } 87 \% \text { of Nevada's land is managed by federal agencies. Is the remaining } 13 \% \text { important for both } \\
\text { livestock production and wildlife habitat? }\end{array}$ & 81 & 7 & 11 \\
\hline Are riparian areas (vegetation adjacent to streams and springs) important for wildlife habitat? & 96 & 3 & 2 \\
\hline Are these riparian areas important for livestock production? & 73 & 16 & 11 \\
\hline Should the proper functioning of riparian areas be an important management priority? & 83 & 6 & 10 \\
\hline $\begin{array}{l}\text { Is there a need for continuing education and research with regard to sustainable use of multiple resources } \\
\text { in northern Nevada rangelands? }\end{array}$ & 86 & 6 & 8 \\
\hline
\end{tabular}

*Due to rounding errors, total response \% (by row) may range from 99 to $101 \%$ 


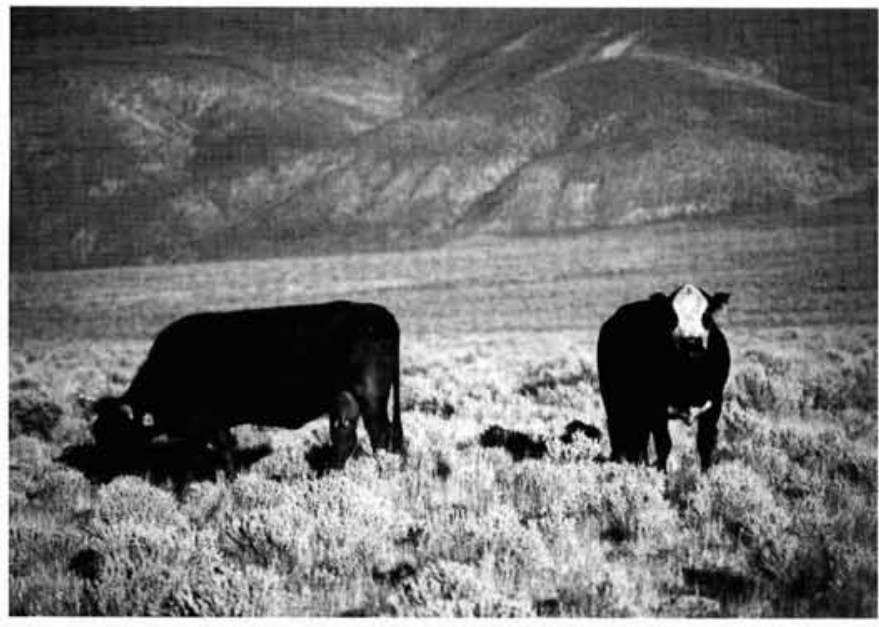

Livestock production was ranked as the third most important use of rangelands behind wildlife and watersheds. Almost $80 \%$ of respondents indicated that livestock and a diversity of wildlife species are compatible on rangelands. (Photo by Ron Torell).

More specifically $78 \%$ said elk, deer, and cattle are compatible on rangelands, and the same percentage indicated that livestock and diverse wildlife species are compatible. A large majority agreed that wildlife diversity in sagebrush habitats should be maintained (Table 4).

Most respondents indicated that mining was compatible with wildlife and livestock production, with $20 \%$ unsure about this relationship (Table 4). As important as consumptive uses obviously were to

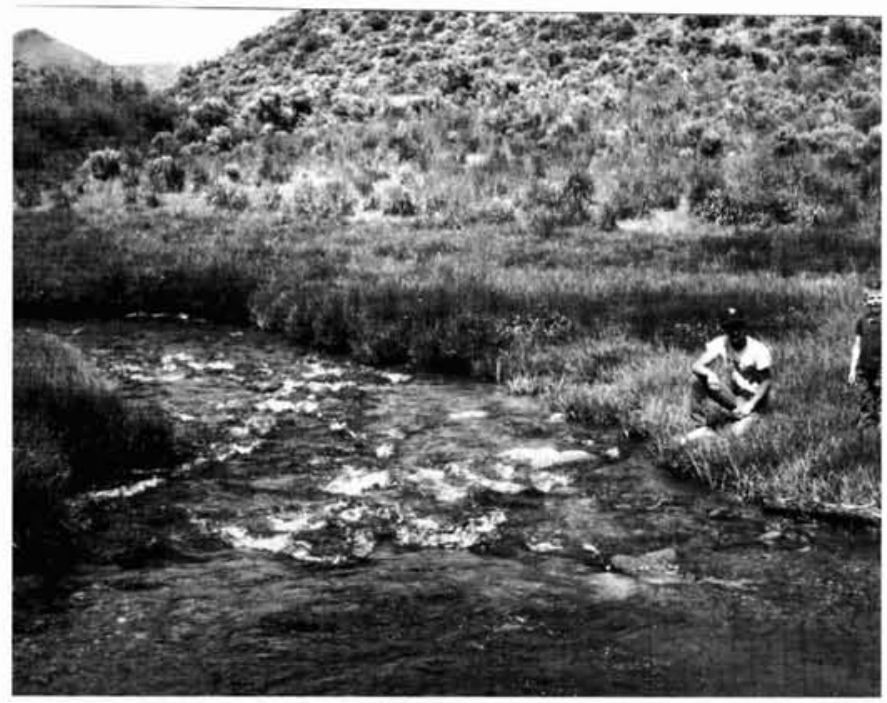

Approximately $83 \%$ of survey respondents considered proper functioning condition of riparian areas an important management priority, and $88 \%$ considered nonconsumptive recreation an important use of rangelands. the survey respondents, $88 \%$ indicated that nonconsumptive (recreational) uses are also important. Respondents also indicated the $13 \%$ of Nevada's land that is privately owned is important for both livestock production and wildlife habitat.

The response to three questions about riparian areas showed the value placed on these areas by the respondents (Table 4). Riparian areas were identified as important wildlife habitat and as important for livestock production by $96 \%$ and $73 \%$ of the respondents, respectively. Accordingly, most respondents indicated that proper functioning condition of these areas was important. A large majority of respondents agreed that there is a need for continuing education and research on sustainable use of multiple resources in northern Nevada.

Survey takers were asked to rank the perceived needs of ten audiences for education about sustainable/multiple use of resources in northern Nevada. Youth were identified as having great education need, followed closely by legislators, then teachers, the general public, local government officials, and environmentalists (Table 5). Those audiences requiring less education about sustainable/multiple use, according to the respondents, are miners, ranchers, and agency personnel. However, even these three audiences were recognized by approximately two-thirds of the respondents as having great educational needs.

Table 5. Perceived needs of various audiences for education about sustainable/multiple use of resources

\begin{tabular}{l|c}
\hline \hline Audience & $\begin{array}{l}\text { Rated as Having Great Need } \\
\text { (\% of Survey Respondents) }\end{array}$ \\
\hline Youth & 85 \\
\hline Legislators & 84 \\
\hline Teachers & 78 \\
\hline General public & 77 \\
\hline Local government officials & 76 \\
\hline Environmentalists & 73 \\
\hline Outdoor enthusiasts & 71 \\
\hline Miners & 67 \\
\hline Rancher & 67 \\
\hline Agency personnel & 67 \\
\hline
\end{tabular}

\section{Resource Conflict Resolution}

Respondents were asked to rate eight potentially controversial rangeland issues on a scale of 1 (very important) to 5 (not important). Of these issues, wildfire revegetation, wildlife (general), and livestock grazing were ranked as the top three issues 
(Table 6). In order, these were followed by the issues of mined land revegetation, wilderness, land exchanges, roadless areas, and threatened and endangered species.

Table 6. Ranked importance of controversial rangeland issues

\begin{tabular}{l|c}
\hline \hline Issue & $\begin{array}{c}\text { Rated as Important to Very Important } \\
\text { (\% of Survey Respondents) }\end{array}$ \\
\hline Wildfire revegetation & 75 \\
\hline Wildlife (general) & 69 \\
\hline Livestock grazing & 68 \\
\hline Mined land revegetation & 65 \\
\hline Wilderness & 62 \\
\hline Exchanges of public and private lands & 57 \\
\hline Roadless areas & 53 \\
\hline Threatened and endangered species & 52 \\
\hline
\end{tabular}

Four specific questions were asked about threatened and endangered species. A substantial majority of the respondents were unaware that the spotted frog is being considered as a candidate for threatened or endangered status listing by the U.S. Fish and Wildlife Service. Approximately half did not know that sage grouse have been petitioned by environmental organizations for listing as threatened or endangered (Table 7). However, most respondents thought their livelihood or lifestyle is potentially affected by classification of wildlife species as threatened or endangered. A large majority $(83 \%)$ of respondents indicated that threatened and endangered species and livestock can co-exist on Nevada's rangelands.

In terms of resolving resource use conflicts, $80 \%$ of the respondents preferred a collaborative citizens' participation or "grassroots" approach to debating these conflicts in the courts (Table 7). However, approximately half were unaware of any collaborative approaches to resource conflict resolution in their counties. Almost two-thirds of respondents indicated that they or someone they know would be willing to work with a citizen's group to identify and discuss natural resource issues. A large majority of respondents indicated there is a need for continuing education regarding the process of collaborative discussion and resolution of natural resource issues/conflicts.

\section{General Questions}

The vast majority of respondents (93\%) thought that the economic health of communities and families should be considered in public land manage-

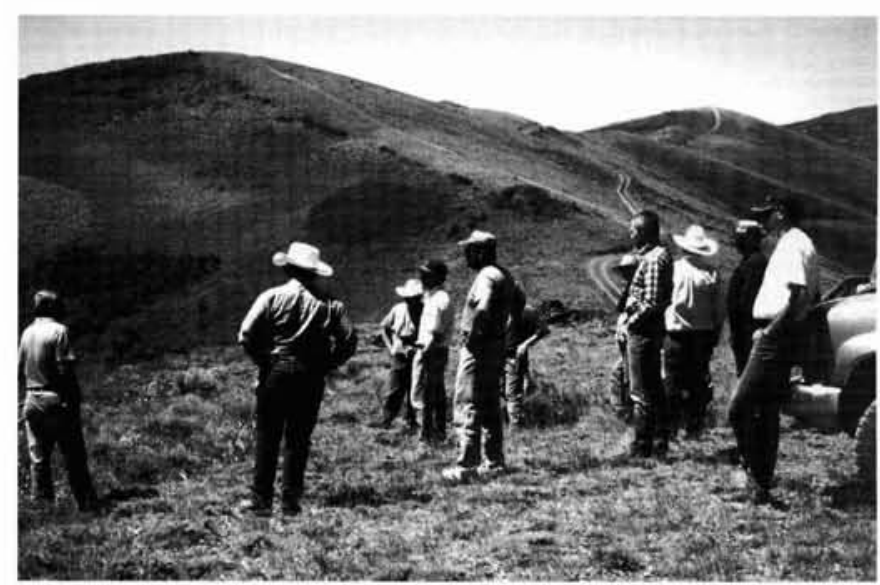

Eighty percent of survey respondents think that a process of collaborative citizen's participation or "grassroots" approach to resolving resource issues is preferable to debating these issues in the courts.

ment decisions. Similarly, $89 \%$ indicated that the ranching heritage on our public lands should be considered in the land management process, and $92 \%$ think that public land managers should make balanced decisions that consider the economic and cultural welfare of rural communities equally with environmental considerations.

\section{Overall Observations}

Northeast Nevadans are keenly aware of the issues, concerns, and opportunities associated with natural resources on rangelands. In order to priori-

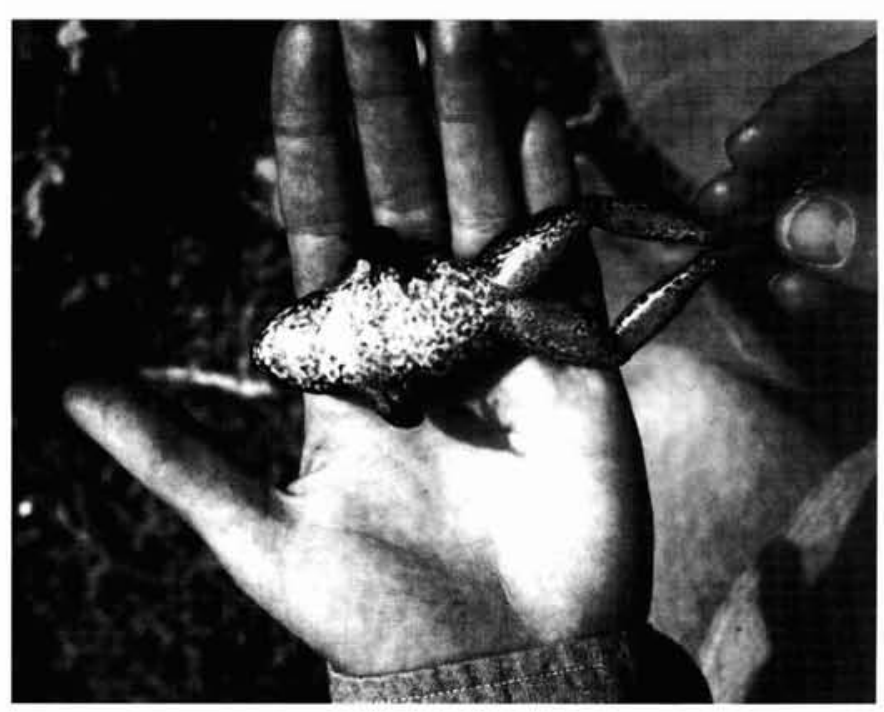

Approximately $21 \%$ of respondents were unaware that the spotted frog may soon be evaluated for federal listing as threatened or endangered, but $62 \%$ think their livelihoods or lifestyles may be affected by classification of wildlife species as threatened or endangered. 
Table 7. Survey responses to questions about potentially controversial rangeland issues

\begin{tabular}{|c|c|c|c|}
\hline \multirow[t]{2}{*}{ Questions } & \multicolumn{3}{|c|}{ Responses (by \%) } \\
\hline & Yes & No & Unsure \\
\hline $\begin{array}{l}\text { Are you aware that the spotted frog may be evaluated soon by the U.S. Fish and Wildlife Service } \\
\text { to determine whether it should be listed as threatened or endangered? }\end{array}$ & 21 & 73 & 6 \\
\hline $\begin{array}{l}\text { Are you aware that the sage grouse has been petitioned for listing as threatened or endangered by } \\
\text { a coalition of environmental organizations? }\end{array}$ & 48 & 50 & 2 \\
\hline $\begin{array}{l}\text { Do you think your livelihood or lifestyle is potentially affected by classification of wildlife species as } \\
\text { threatened or endangered? }\end{array}$ & 62 & 30 & 8 \\
\hline Do you think that endangered species and livestock can co-exist on our rangelands? & 83 & 5 & 13 \\
\hline $\begin{array}{l}\text { Do you think that a process of collaborative citizens' participation or "grassroots" } \\
\text { approach to resolving resource issues is more worthwhile than debating these issues in the courts? }\end{array}$ & 80 & 4 & 16 \\
\hline $\begin{array}{l}\text { Are you aware of the efforts of any collaborative processes such as coordinated resource management } \\
\text { (CRM), holistic management (HM), resource stewardship groups, or other grassroots resource efforts } \\
\text { in your county? }\end{array}$ & 35 & 53 & 13 \\
\hline $\begin{array}{l}\text { Would you or someone you know be willing to work with a citizen's group to identify and discuss natural } \\
\text { resource issues? }\end{array}$ & 64 & 16 & 21 \\
\hline $\begin{array}{l}\text { Is there a need for continuing education with regard to the process of collaborative discussion and resolution? } \\
\text { of natural resource issues? }\end{array}$ & 86 & 6 & 8 \\
\hline
\end{tabular}

tize issues deemed most important by the survey respondents, I considered those rangeland productivity and sustainable/multiple use issues with importance values greater than $75 \%$ (see Tables 1 and 3 ) to be the highest priority natural resource issues in northeast Nevada. Therefore, the priority rangeland productivity challenges are over-all rangeland ecological health, noxious weed control, and burned area rehabilitation. The priority sustainable/multiple use categories are wildlife habitat and species diversity, watershed, and livestock forage.

Respondents perceived a high degree of compatibility between livestock and wildlife on rangelands, and indicated that wildlife diversity can and should be maintained. In relation to watershed management, respondents identified the riparian vegetation adjacent to streams and springs as being very important for both wildlife and livestock, and as having high management priority. The respondents were not only interested in consumptive use of resources and economic prosperity, but also valued nonconsumptive (recreational) uses very highly. Approximately $86 \%$ of the respondents indicated a need for continuing education and research with regard to restoring rangeland productivity, multiple use of rangeland resources, and resolution of natural resource issues.

Land managers in northeast Nevada can use the results of this survey to help set priorities in rangeland management. The public desires healthy rangelands that produce ecological diversity, economic prosperity, and recreational opportunity. Perhaps effective multiple use management is important now more than ever.

About the author: J. Kent McAdoo is rangeland resources specialist, University of Nevada Cooperative Extension, Northeast Extension Area, Elko, Nevada 89801. 